\title{
The new environmental security: Linking food, water, and energy for integrative and diagnostic social-ecological research
}

\author{
Philip A. Loring, ${ }^{\text {* }}$ S. Craig Gerlach, ${ }^{\mathrm{b}}$ University of Alaska Fairbanks \\ Henry P. Huntington, ${ }^{c}$ Huntington Consulting
}

Submitted June 4, 2013 / Revised July 10, 2013 / Published online July 19, 2013

Citation: Loring, P. A., Gerlach, S. C., \& Huntington, H. P. (2013). The new environmental security: Linking food, water, and energy for integrative and diagnostic social-ecological research. Journal of Agriculture, Food Systems, and Community Development, 3(4), 55-61. http://dx.doi.org/10.5304/jafscd.2013.034.005

Copyright (C) 2013 by New Leaf Associates, Inc.

\begin{abstract}
In this commentary we describe a new framework for environmental security, one that draws food, water, and energy security into a unified socioecological research program. While traditional uses of environmental security carry statist and militaristic undertones, we propose that this "new" environmental security provides a more comprehensive perspective for research and

\footnotetext{
a Water and Environmental Research Center, University of Alaska Fairbanks; P.O. Box 755910; Fairbanks, Alaska 99775 USA Fairbanks; P.O. Box 756730; Fairbanks, Alaska 99775 USA

c Huntington Consulting; 23834 The Clearing Drive; Eagle River, Alaska 99577 USA

* Corresponding author: Philip A. Loring; +1-907-474-7163; ploring@alaska.edu
}

b Center for Cross-Cultural Studies, University of Alaska
\end{abstract}

development. Individually, food, water, and energy security research have made great progress, and as we describe here, the three have converged upon a core set of constituent properties: availability, access, utility, and stability. Yet, tradeoffs and interactions between food, water, and energy systems, which we argue tend to be place-based and which we illustrate using some examples from Alaska, are infrequently researched and not well captured in most global frameworks for integrated assessment. We present this integrative framework for environmental security, and conclude with suggestions regarding broad research themes and priorities.

\section{Keywords}

Alaska, Arctic, energy security, environmental security, food security, social-ecological systems, water security 


\section{Introduction}

The concept of environmental security, in the way that it is most frequently used in North American and European policy and international development discourse, is concerned primarily with threats posed by nonlinear environmental trends and extreme events, with particular emphasis on how these might infringe on national territories, sovereign power, and the state's capacity to ensure the security of its constituents (Lodgaard, 1992; Myers, 1996). In this commentary, however, we suggest an alternative framework within which to consider environmental security, one loosened from the more conventional "homeland security" model that is statist and militaristic, and one that we feel provides a more comprehensive perspective for research and development through the integration of food, water, and energy security concerns (Millennium Project, 2005). As we describe below, this new environmental security framework situates food, water, and energy within a complex, interrelated, and dynamic system that is best researched and developed in an integrated and appropriately scaled fashion.

Food, water, and energy systems have all been identified as key problem areas for interdisciplinary research and international development (Dunn \& Bakker, 2011; Ericksen Stewart, Dixon, Barling, Loring, Anderson, \& Ingram, 2010; Falkenmark \& Rockstrom, 2004; Hamilton, White, Lammers, \& Myerchin, 2011; Sovacool \& Brown, 2010). Likewise, linkages and interactions among the three sectors are numerous, with many of the most obvious connections comparatively well described. For example, water rights, allocation, and quality all contribute greatly to agricultural productivity, both directly through cropping and irrigation strategies, and indirectly through hydrological influences on regional weather, biodiversity, and ecosystem services (Falkenmark, 1977; Food and Agriculture Organization of the United Nations [FAO], 2002). Similarly, food and energy systems are closely coupled, especially in energy-intensive food production and distribution systems (Pirog, Van Pelt, Enshayan, \& Cook, 2001; Von Braun, 2008). Biofuels have added a new dimension here as well, with some viewing biofuel development as potentially shifting arable land from food to energy production purposes, and with this viewed as a negative rather than a positive outcome $(\mathrm{M}$. E. Brown \& Funk, 2008; Tangermann, 2008; Tilman et al., 2009).

These general themes and relationships can easily be anticipated, but regional- and local-level dynamics among food, water, and energy are often far more complex and place-based. However, local and regional levels of analysis are not well captured in most global frameworks for integrated assessment, which often define temporal and spatial scales rather loosely and emphasize directional change over nonlinear system dynamics (Arctic Council, 2013; L. R. Brown, 2009; Millennium Ecosystem Assessment, 2005). At this point there is still far too little research focused on the inherent complexities and interconnections between water, food, and energy systems as complex, socialecological systems (Falkenmark, 2001), although calls for new emphases are found for more integrative and interdisciplinary research frameworks for each of the three sectors (Ericksen et al., 2010; Gerlach, Loring, \& Turner, 2011; Sivapalan, Savenije, \& Blöschl, 2012; Sovacool \& Brown, 2010). Sivapalan and colleages (2012), for example, argue that,

Natural scientists have for too long ignored the human factor. Hydrologists are not exceptions to this. In traditional hydrology, human-induced water resources management activities are prescribed as external forcings in the water cycle dynamics, under the assumption of stationarity....In sociohydrology, humans and their actions are considered part and parcel of water cycle dynamics, and the aim is to predict the dynamics of both. (p. 1271)

Likewise, Ericksen and colleagues (2010) argue the following about food security:

As food systems encompass social, economic and political issues as well as ecological, different disciplines must be bridged in order to develop a holistic analytical or research framework. (p. 25) 


\section{Trade-offs and Interactions}

Ideally, food, water, and energy security can be mutually supporting goals, meaning that solutions for one system component need not compromise or otherwise detract from the others. In practice, however, trade-offs among the three seem inevitable. In Alaska, for example, where much rural food security is obtained through the harvest of traditional subsistence fish and game, the cost of gasoline can be prohibitive, such that long excursions for the successful harvest of these "country foods" involves the high costs of fueling boats and allterrain vehicles, and purchasing and maintaining the new equipment that is necessary to support the modern, high-tech, subsistence lifestyle. New industrial-scale energy development in the increasingly ice-free and/or ice-compromised arctic waters, which some argue will mitigate future gasoline prices and improve regional energy security, may also detract from subsistence activities through environmental impacts on highly valued subsistence species such as seals, walruses, and caribou (National Research Council, 2003). Similarly, hydroelectric projects are being explored in many parts of Alaska (Cherry, Walker, Fresco, Trainor, \& Tidwell, 2010), but residents of Alaska communities, rural and urban alike, rely quite heavily on riverine fisheries for food security (e.g., Loring, Gerlach, \& Harrison, 2013). Yet, unless new renewable energy sources are developed, climate change as a result of global $\mathrm{CO}_{2}$ emissions will continue to disrupt the natural ecosystems and biodiversity that underpin food security and local livelihoods across Alaska and the rest of the North American Arctic and Subarctic. Thus there is a real possibility that actions taken to ensure one sector of environmental security, e.g., energy security, can create complex trade-offs with other sectors, e.g., food security, and this in itself is an undesirable outcome that situates the problem at least in part in the context of planning and policy formulation.

Given these factors, we argue that, while food, water, and energy security research continue to be important individually_using the "silo approach," if you will-it is also imperative that new research address the intersection of these three sectors, in order to understand the circumstances under which synergies and/or trade-offs among the three emerge. We will then understand through this intersection that these are emergent properties rather than state conditions, with the latter being typical of most formulations constructed through resilience theory (Chapin III, Kofinas, \& Folke, 2009). In working toward an alternative end, one that we hope will ultimately be more useful, we offer the outline for a different framework below.

\section{Availability, Access, Utilization}

Multiple analytical frameworks and heuristics benefit the analysis of food, water, and energy systems (e.g., Alessa, Kliskey, Lammers, Arp, White, Hinzman, \& Busey, 2008; Barrett, 2010; Cook and Bakker, 2012; Ericksen et al., 2010; Sovacool \& Brown, 2010; Vörösmarty et al., 2010). While a comprehensive and comparative review of these is beyond the scope of this commentary (although this would be an excellent contribution to the literature), many of these frameworks employ some variation of four interrelated concepts: availability, or whether the resource (e.g., food) is produced in sufficient quantities; access, or whether people have the necessary rights and financial resources to procure the resource in sufficient quantities; utilization, or whether the resource that people access meets all of their needs (e.g., biophysical, sociocultural); and stability, or how the previous three change individually or in concert over time. These concepts are arguably most commonly associated with food security frameworks, but more recent research focused on energy and water security also invoke these concepts implicitly, if not explicitly (table 1).

The next step needed for substantive research into these linked domains, we argue, is to apply a diagnostic approach to mapping out the various feedbacks and interactions among the three (figure 1), with specific reference to availability, access, utility, and stability, via both case studies and comparative efforts (Agrawal, 2001). Do programs to improve security in one domain reduce security in others, and if so, why?

Any number of diagnostic frameworks could be applied to such studies, for example from a multistakeholder, ecosystem services perspective (e.g., Loring, Chapin III, \& Gerlach, 2008), or from a common pool resource system perspective (e.g., 
Table 1. The Four Components of Food Security and their Analogs in Water and Energy Security

\begin{tabular}{|c|c|c|c|}
\hline & $\begin{array}{l}\text { Food Security } \\
\text { (Ericksen et al., 2010) }\end{array}$ & $\begin{array}{l}\text { Water Security } \\
\text { (Cook \& Bakker, 2012) }\end{array}$ & $\begin{array}{l}\text { Energy Security } \\
\text { (Sovacool \& Brown, 2010) }\end{array}$ \\
\hline Availability & $\begin{array}{l}\text { The amount, type, and quality of a } \\
\text { food available through local } \\
\text { production, distribution channels, } \\
\text { and exchange of money. }\end{array}$ & $\begin{array}{l}\text { “Water supply," often with respect } \\
\text { to withdrawals or population size } \\
\text { and/or needs. }\end{array}$ & $\begin{array}{l}\text { "Availabilty," as the relative safety } \\
\text { and source diversification of energy } \\
\text { fuels and services. }\end{array}$ \\
\hline Access & $\begin{array}{l}\text { The ability to gain access to the } \\
\text { type, quality, and quantity of food } \\
\text { required, in terms of affordability } \\
\text { and allocation mechanisms. }\end{array}$ & $\begin{array}{l}\text { "Human needs," including access } \\
\text { and affordability in sufficient } \\
\text { quantities to protect health, } \\
\text { safety, welfare, etc. }\end{array}$ & $\begin{array}{l}\text { "Affordability," as equitable access } \\
\text { to energy services in terms of cost } \\
\text { and service and infrastructure. }\end{array}$ \\
\hline Utility & $\begin{array}{l}\text { The ability to consume and } \\
\text { benefit from foods nutritionally, } \\
\text { psychologically, and } \\
\text { psychosocially. }\end{array}$ & $\begin{array}{l}\text { Not explicitly identified, but } \\
\text { quality, e.g., pollution and } \\
\text { salination, are discussed. }\end{array}$ & $\begin{array}{l}\text { "Efficiency," as the improved } \\
\text { performance and increased } \\
\text { deployment of more efficient } \\
\text { equipment and conservation. }\end{array}$ \\
\hline Stability & $\begin{array}{l}\text { How all of the above function over } \\
\text { time, including predictability and } \\
\text { reliability. }\end{array}$ & $\begin{array}{l}\text { “Sustainability," including water } \\
\text { stress or shortages and also } \\
\text { water-related hazards and } \\
\text { vulnerability of water systems }\end{array}$ & $\begin{array}{l}\text { “Environmental stewardship," } \\
\text { emphasizing the importance of } \\
\text { sustainability of energy systems } \\
\text { over time. }\end{array}$ \\
\hline
\end{tabular}

Figure 1. The New Environmental Security Framework

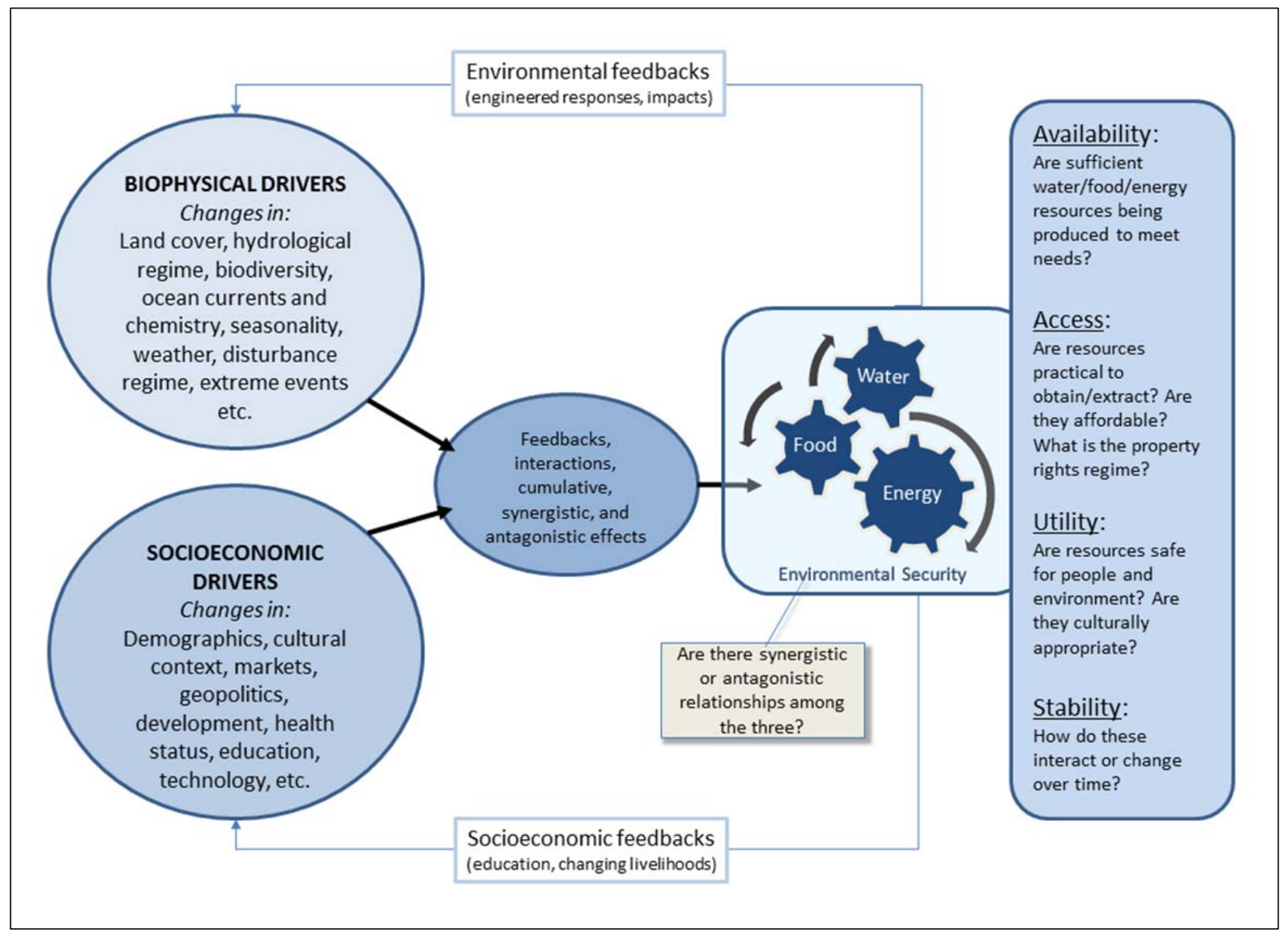


Ostrom, 2007), to name two. Following Ostrom (2007), we are particularly interested in the patterns of interactions and outcomes that can occur among food, water, and energy systems, patterns that can include overuse, conflict, collapse, stability, or increasing returns, in one domain of environmental security due to changes in the technological, socioeconomic, and political environments of another. In other words, how robust and sustainable is a particular food, water, or energy system, and how will it be affected by disturbances and/or developments in any one of the other environmental security domains described above?

Interactions among scales and levels and from region to region are also key areas for research (see e.g., Eakin \& Wehbe, 2009; Sneddon \& Fox, 2006). If food, water, and energy security all have placebased components, then the resulting heterogeneous landscape of systems and solutions is sure to involve conflicts and trade-offs that need to be resolved or at least managed effectively, at the appropriate social and political level of organization, and at the appropriate spatial and temporal scale (Redpath et al., 2013).

Research on these questions could take a historical social, cultural, and ecological perspective, for example, tracing the impacts of past development in one domain (e.g., a hydroelectric project), through subsequent demographic, sociocultural, economic, and environmental responses and outcomes in others (e.g., changes in demography (in/out migration), energy use, food security, and public health). As historical research clearly shows, more concrete scenarios planning and modeling work regarding the relationships among food, water, and energy security could provide a forward-looking perspective to better project the impacts of new development or such large-scale drivers as global environmental change. Likewise, an important contribution from case studies is the ability to identify positive as well as negative impacts and outcomes. Too often, assessments of impacts are biased toward the negative (Haalboom \& Natcher, 2012), perhaps because it is easier to see how existing structures will be disrupted than to foresee new structures that may emerge. The goal, ultimately, is to develop better scientific understandings of the linked social and ecological dynamics of food, water, and energy systems and security, both as a subject of research and as a matter of informing effective policy and development if we are to move forward with well-informed solutions to these complex problems.

\section{Acknowledgements}

The framework and ideas presented here originated in a development research proposal to the National Science Foundation by the authors and also in collaboration with Dr. William E. Schnabel, University of Alaska Fairbanks (UAF); Dr. Andrew Metzger, UAF; Dr. Larry Hinzman, UAF; Dr. John Walsh, UAF; Dr. Shari Gearheard, National Snow and Ice Data Center, Boulder, Colorado; Dr. Lawrence Hamilton, University of New Hampshire; and, Dr. Richard Lammers, University of New Hampshire.

\section{References}

Agrawal, A. (2001). Common property institutions and sustainable governance of resources. World Development, 29(10), 1649-1672. http://dx.doi.org/ 10.1016/S0305-750X(01)00063-8

Alessa, L., Kliskey, A., Lammers, R., Arp, C., White, D. M., Hinzman, L. D., \& Busey, R. (2008). The Arctic water resource vulnerability index: An integrated assessment tool for community resilience and vulnerability with respect to freshwater. Environmental Management, 42(3), 523-541. http://dx.doi.org/10.1007/s00267-008-9152-0

Arctic Council. (2013). Arctic Resilience Interim Report 2013 Stockholm: Stockholm Environment Institute and Stockholm Resilience Centre. Retrieved from http://www.seiinternational.org/mediamanager/ documents/Publications/ArcticResilienceInterim Report2013-LowRes.pdf

Barrett, C. B. (2010). Measuring food insecurity. Science, 327(5967), 825-828. http://dx.doi.org/10.1126/ science. 1182768

Brown, L. R. (2009). Plan B 4.0: Mobilizing to save civilization. New York: W. W. Norton \& Company.

Brown, M. E., \& Funk, C. C. (2008). Food security under climate change. Science, 319(5863), 580-581. http://dx.doi.org/10.1126/science.1154102

Chapin III, F. S., Kofinas, G. P., \& Folke, C. (2009). Principles of ecosystem stewardship: Resilience-based natural resource management in a changing world. New York: Springer. 
Cherry, J. E., Walker, S., Fresco, N., Trainor, S., \& Tidwell, A. (2010). Impacts of climate change and variability on bydropower in southeast Alaska: Planning for a robust energy future. Retrieved from http://ine.uaf. edu/accap/documents/seak report final.pdf

Cook, C., \& Bakker, K. (2012). Water security: Debating an emerging paradigm. Global Environmental Change, 22(1), 94-102. http://dx.doi.org/10.1016/j.gloenvcha.2011.10.011

Dunn, G., \& Bakker, K. (2011). Fresh water-related indicators in Canada: An inventory and analysis. Canadian Water Resources Journal, 36(2), 135-148. http://dx.doi.org/10.4296/cwrj3602815

Eakin, H., \& Wehbe, M. (2009). Linking local vulnerability to system sustainability in a resilience framework: Two cases from Latin America. Climatic Change, 93(3), 355-377. http://dx.doi.org/10.1007/s10584-008-9514-x

Ericksen, P. J., Stewart, B., Dixon, J., Barling, D., Loring, P. A., Anderson, M., \& Ingram, J. (2010). The value of a food system approach. In Food Security and Global Environmental Change (pp. 25-45). London: Earthscan.

Falkenmark, M. (1977). Water and mankind: A complex system of mutual interaction. Ambio, 6(1), 3-9. http://dx.doi.org/10.2307/4312233

Falkenmark, M. (2001). The greatest water problem: The inability to link environmental security, water security and food security. International Journal of Water Resources Development, 17(4), 539-554. http://dx.doi.org/10.1080/07900620120094073

Falkenmark, M., \& Rockstrom, J. (2004). Balancing Water for Humans and Nature: The New Approach in Ecohydrology. London: Earthscan.

Food and Agriculture Organization of the United Nations [FAO]. (2002). Crops and drops: Making the best use of water for agriculture. Rome: FAO. Retrieved from http://www.fao.org/docrep/005/y3918e/ y3918e00.HTM

Gerlach, S. C., Loring, P. A., \& Turner, A. M. (2011). Food systems, climate change, and community needs. In H. Eicken \& A. L. Lovecraft (Eds.), North by 2020. Fairbanks, Alaska: University of Alaska Press.

Haalboom, B., \& Natcher, D. C. (2012). The power and peril of "vulnerability": Approaching community labels with caution in climate change research. ARCTIC, 65(3), 319-327.
Hamilton, L. C., White, D. M., Lammers, R. B., \& Myerchin, G. (2011). Population, climate, and electricity use in the Arctic integrated analysis of Alaska community data. Population and Environment, 33(4), 269-283. http://dx.doi.org/10.1007/s11111011-0145-1

Lodgaard, S. (1992). Environmental security, world order, and environmental conflict resolution. In $\mathrm{N}$. P. Gledisch (Ed.), Conversion and the Environment: Proceeding of a seminar in Perm, Russia. 24-7 November 1991. Prio Report No. 2 (pp. 115-136).

Loring, P. A., Chapin III, F. S., \& Gerlach, S. C. (2008). The services-oriented architecture: Ecosystem services as a framework for diagnosing change in social ecological systems. Ecosystems, 11(3), 478-489.

Loring, P. A., Gerlach, S. C., \& Harrison, H. L. (2013). Seafood as local food: Food security and locally caught seafood on Alaska's Kenai Peninsula. Journal of Agriculture, Food Systems, and Community Development, 3(3), 13-30. http://dx.doi.org/10.5304/jafscd.2013.033.006

Millennium Ecosystem Assessment. (2005). Ecosystems and human well-being: Synthesis. Washington, D.C.: Island Press. Retrieved from http://www.maweb. org/documents/document.356.aspx.pdf

Millennium Project. (2005). Investing in development: $A$ practical plan to acheive the millennium development goals. New York, NY: United Nations. Retrieved from http://www.unmillenniumproject.org/reports/ fullreport.htm

Myers, N. (1996). Ultimate security: The environmental basis of political stability. Washington, D.C.: Island Press.

National Research Council. (2003). Cumulative environmental effects of Alaskan North Slope oil and gas activities. Washington, D.C.: National Academies Press.

Ostrom, E. (2007). A diagnostic approach for going beyond panaceas. Proceedings of the National Academy of Sciences, 104(39), 15181-15187.

Pirog, R., Van Pelt, T., Enshayan, K., \& Cook, E. (2001). Food, fuel, and freeways. Ames, Iowa: Leopold Center for Sustainable Agriculture, Iowa State University.

Redpath, S. M., Young, J., Evely, A., Adams, W. M., Sutherland, W. J., Whitehouse, A.,...Gutiérrez, R. J. (2013). Understanding and managing conservation conflicts. Trends in Ecology \& Evolution, 28(2), 100109. http://dx.doi.org/10.1016/j.tree.2012.08.021 
Sivapalan, M., Savenije, H. H. G., \& Blöschl, G. (2012). Socio-hydrology: A new science of people and water. Hydrological Processes, 26(8), 1270-1276. http://dx.doi.org/10.1002/hyp.8426

Sneddon, C., \& Fox, C. (2006). Rethinking transboundary waters: A critical hydropolitics of the Mekong basin. Political Geography, 25(2), 181-202. http://dx.doi.org/10.1016/i.polgeo.2005.11.002

Sovacool, B. K., \& Brown, M. A. (2010). Competing dimensions of energy security: An international perspective. Annual Review of Environment and Resources, 35(1), 77-108. http://dx.doi.org/ 10.1146/annurev-environ-042509-143035

Tangermann, S. (2008). Biofuels and food security. Rural 21, 13(2), 30-32.
Tilman, D., Socolow, R., Foley, J. A., Hill, J., Larson, E., Lynd, L.,...Williams, R. (2009). Beneficial biofuels - The food, energy, and environment trilemma. Science, 325(5938), 270-271. http://dx.doi.org/10.1126/science. 1177970

Von Braun, J. (2008). Rising food prices: What should be done? [IFPRI Policy Brief]. Washington, D.C.: International Food Policy Research Institute. Retrieved from http://www.ifpri.org/blog/risingfood-prices-what-should-be-done

Vörösmarty, C. J., McIntyre, P. B., Gessner, M. O., Dudgeon, D., Prusevich, A., Green, P.,...Davies, P. M. (2010). Global threats to human water security and river biodiversity. Nature, 467(7315), 555-561. http://dx.doi.org/10.1038/nature09440 